\title{
Multiplex PCR to Detect T. gondii Infection based on B1 Gene and 529 bp Repetitive Element
}

Yenisey Alfonso ${ }^{1 *}$, Jorge Fraga ${ }^{1}$, Zhaily González ${ }^{1}$, Narciso Jiménez² $^{2}$ Yainais Borrero², Raymundo Cox ${ }^{1}$, Carlos Fonseca ${ }^{2}$, Francisco Bandera $^{2}$, Virginia Capó ${ }^{2}$ and Dora Ginorio ${ }^{1}$

${ }^{1}$ Parasitology Department, Institute of Tropical Medicine "Pedro Kourí, Cuba

${ }^{2}$ Health Care Division, Institute of Tropical Medicine "Pedro Kourí, Cuba

\begin{abstract}
Polymerase Chain Reaction (PCR) has made a significant improvement in the diagnosis of toxoplasmosis. Nevertheless, a wide variety of targets and primers has been evaluated in different independent assays, and only few comparative studies have been performed. Even when the B1 gene and the 529 repetitive element have been the most studied markers, there no concluding remarks respect the best.
\end{abstract}

Objetive: The aim of the present study was to design a multiplex PCR assay to simultaneously detect these two markers in a single multiplex PCR to diagnose $T$. gondii infection.

Methods: Specific PCR primers targeting the B1 gene and 529 repetitive element were evaluated. After a careful optimization of multiplex PCR process, analytical sensitivity and specificity were evaluated. The usefulness of multiplex assay was evaluated using DNA from $8 T$. gondii reference strains, corresponding to the three principal genotypes, and 70 clinical samples (blood) from AIDS patients with and without Toxoplasmic encephalitis (TE).

Results: Our preliminar results show that multiplex PCR assay is able to amplify both targets in using DNA from one parasite in the mix PCR reaction. Unspecific reactions for other microorganisms were not observed. The diagnostic sensitivity of multiplex assay in blood, according to the Centers for Disease Control and Prevention (CDC) criteria, was $86.6 \%$ while the diagnostic specificity was $100 \%$. Only one sample was positive to one marker (B1 gene) in the multiplex reaction.

Conclusion: This multiplex PCR method is the first multiplex PCR evaluating the detection of $T$. gondii DNA in TE cases and it proved to be rapid, enough sensitive, highly specific and inexpensive respect to perform independent assays for each marker, real time PCR or nested PCR assays.

Keywords: Multiplex PCR; TE; AIDS; Toxoplasma gondii

\section{Introduction}

Toxoplasma gondii is a widely distributed apicomplexan parasite of great medical importance infecting all mammalian cells. During acute infection, T. gondii differentiates into tissue cysts, residing principally in the muscles and brain. Symptomatic forms can occur when primary infection appears during pregnancy, which can result in severe neonatal malformations and ocular complications in the fetus. In patients infected with human immunodeficiency virus (HIV), low levels of $\mathrm{CD} 4^{+} \mathrm{T}$ cells allow reactivation of the latent infection. Parasite proliferation result in symptomatic disease (Toxoplasmic Encephalitis (TE)), a life-threatening condition without timely diagnosis and treatment $[1,2]$.

TE remains a prevalent disorder of the Central Nervous System, particularly among severely immunosuppressed HIV-infected patients in the absence of antibiotic prophylaxis [3]. Its incidence among HIVinfected individuals correlates directly with the prevalence of anti-T. gondii antibodies in general population. It represents the most common cerebral mass lesion in AIDS patients, despite free access to Highly Active Antiretroviral Treatment (HAART) [4].

The use of molecular diagnosis is particularly appropriate for such patients, since it does not depend on the immunological status of the host. Molecular diagnosis based on conventional PCR has become an indispensable tool for TE [5-9]. However, as consequence of several factors, twenty five year after the introduction of PCR in the diagnostic of toxoplasmosis, there is not a consensus respect the best molecular method, marker o set of primers to diagnose the disease.
In this scenario, two targets have been preferentially used (B1 gene and the 200 to 300 -fold repeated 529 bp fragment) [10,11] and its efficacy have been compared in some studies [12-21]. In addition, both targets are used as routine in independent assays to confirm the diagnosis of the disease, but this procedure is more expensive and time consuming [21]. The objective of this study was to investigate how effective is to amplify both targets in the same PCR reaction, and evaluate this methodology to diagnose T. gondii infection in AIDS patients.

\section{Material and Methods}

\section{Parasite preparation}

T. gondii RH tachyzoites $\left(2 \times 10^{5} / \mathrm{ml}\right)$ were inoculated intraperitoneally in five OF1 Swiss mouse. Tachyzoites were harvested three days later from peritoneal lavage collected in $5 \mathrm{ml}$ of phosphate-

*Corresponding author: Yenisey Alfonso, Toxoplasma Laboratory/Molecular Biology Laboratory, Parasitology Department, Institute of Tropical Medicine "Pedro Kouri".PO Box 601, Marianao 13, La Habana, Cuba, Tel: 53-7-202-0633; Fax: 53-7204-6051; E-mail: yenisey@ipk.sld.cu

Received October 01, 2015; Accepted February 27, 2015; Published March 06 2015

Citation: Alfonso Y, Fraga J, González Z, Jiménez N, Borrero Y, et al. (2015) Multiplex PCR to Detect $T$. gondii Infection based on B1 Gene and 529 bp Repetitive Element. J AIDS Clin Res 6: 435. doi:10.4172/2155-6113.1000435

Copyright: ( 2015 Alfonso Y, et al. This is an open-access article distributed under the terms of the Creative Commons Attribution License, which permits unrestricted use, distribution, and reproduction in any medium, provided the original author and source are credited. 
buffered saline (PBS), and centrifuged at $1000 \mathrm{X}$ g for $10 \mathrm{~min}$. The pelleted parasites were suspended and washed twice in PBS. Cells were counted in a Neubauer chamber and diluted in PBS to a concentration of $11.2 \times 10^{6} \mathrm{cells} / \mathrm{ml}$.

For Me49, C56, Tg51 and Prug strains, brain tissue, at least 8 weeks post inoculation, were homogenized independently in $1 \mathrm{ml}$ of PBS and frozen at $-20^{\circ} \mathrm{C}$ until DNA extraction.

For $\mathrm{OH} 3$ strain, fresh parasites were maintained in culture on human fibroblast (Dulbecco's medium and 10\% de fetal bovine serum, $1 \mathrm{mM}$ glutamine and $10 \mu \mathrm{g} / \mathrm{mL}$ gentamicin) (Sigma, ST Louis, MO, EEUU). Parasites were incubated at $37^{\circ} \mathrm{C}$ in $5 \%$ de $\mathrm{CO}_{2}$ After five days, parasites were collected from the culture and store at $-20^{\circ} \mathrm{C}$ until DNA extraction.

\section{Patients}

The study included 70 AIDS patients admitted to the clinical wards at the Institute of Tropical Medicine "Pedro Kourí", Havana, Cuba. Neurological symptoms were present in all of them.

Patients were divided into two groups according to the CDC criteria for AIDS related TE [22]. Group I consisted of 30 AIDS patients with TE and Group II consisted of 40 patients with other AIDS-related disorders.

Five $\mathrm{ml}$ of blood in one $\mathrm{ml}$ of Acid Citrate Dextrose (ACD) was collected from each patient. After centrifugation, the pellets of cells were stored at $-20^{\circ} \mathrm{C}$ until analyzed.

\section{DNA extraction}

DNA from reference strains was isolated using Promega genomic DNA extraction kit, according to the manufacturer instructions for cell culture or tissue (Promega, USA).

For blood samples, DNA was extracted using phenol-chloroformisoamyl alcohol method [23] taking in to account a comparison of DNA extraction methods (unpublished yet).

\section{Optimization of the Multiplex PCR conditions}

Multiplex PCR included two targets previously reported (B1 gene [10] and the 529 bp repetitive element [11]. B22 and B23 primers, previously reported by Bretagne et al, 1993 [5] were used to amplify a $115 \mathrm{bp}$ fragment from the B1 gene, while $529 \mathrm{~F}$ and $529 \mathrm{R}$ primers were designed in our lab (not published yet) to amplify a PCR product of 393bp from the nucleotide sequence of genomic $529 \mathrm{bp}$ fragment from T. gondii.

The amplification was performed in $25 \mu$ of reaction mixture containing, 1x PCR buffer (Promega, USA) and $200 \mu \mathrm{M}$ dNTPs (Promega, USA). The rest of conditions, primers $(0,2 \mu \mathrm{M}-0,5 \mu \mathrm{M})$; Magnesium chloride (1mM - 4mM) (Promega, USA); and taq polymerase (Promega, USA) $(0,5 \mathrm{U}-2 \mathrm{U})$, were carefully optimized as well as annealing temperature $\left(57^{\circ} \mathrm{C}, 58.6^{\circ} \mathrm{C}, 60.1^{\circ} \mathrm{C}, 61.9^{\circ} \mathrm{C}, 63.4^{\circ} \mathrm{C}\right)$ before start the study (Table 1). RH strain was used as positive control. The primers sequence, size of each fragment and references are summarized in Table 2 .

\section{PCR analytical sensitivity and specificity}

Two-fold serial dilutions ranging from $11.2 \times 10^{6}$ to 1 cell of the parasite (RH strain) were prepared and contaminated with 200 $\mu \mathrm{l}$ of blood (collected from a seronegative person for $T$. gondii).

\begin{tabular}{|l|l|}
\hline Condition & Values evaluated \\
\hline Polymerase enzyme & $0.5 \mathrm{U} ; 1.0 \mathrm{U} ; 1.5 \mathrm{U} ; 2.0 \mathrm{U}$ \\
\hline Primers & $0.2 \mu \mathrm{m} ; 0.3 \mu \mathrm{m} ; 0.4 \mu \mathrm{m} ; 0.5 \mu \mathrm{m}$ \\
\hline Magnesium chloride & $1.0 \mathrm{mM} ; 2.0 \mathrm{mM} ; 3.0 \mathrm{mM} ; 4.0 \mathrm{mM}$ \\
\hline Annealing temperature & $57^{\circ} \mathrm{C} ; 58.6^{\circ} \mathrm{C} ; 60.1^{\circ} \mathrm{C} ; 61.9^{\circ} \mathrm{C} ; 63.4^{\circ} \mathrm{C}$ \\
\hline
\end{tabular}

Table 1: PCR conditions evaluated to optimize the multiplex PCR assay.

\begin{tabular}{|c|c|c|c|}
\hline Primer & Sequence (5'-3') & size (bp) & Reference \\
\hline B22 & TGT TCT GTC CTA TCG CAA CG & \multirow{2}{*}{115} & \multirow{2}{*}{$\begin{array}{l}\text { Bretagne et } \\
\text { al, } 1993\end{array}$} \\
\hline B23 & TGG GTC TAC GTC GAT GGC ATG ACA AC & & \\
\hline $529 \mathrm{~F}$ & GAGACCGCGGAGCCGAAGTGC & \multirow{2}{*}{393} & \multirow{2}{*}{$\begin{array}{l}\text { Present } \\
\text { study }\end{array}$} \\
\hline 529R & ССТССТССТСССТTСGTCСAAG & & \\
\hline
\end{tabular}

Table 2: Primers sequence, size of each fragment and references for each fragment.

DNA was extracted using the phenol-chloroform-isoamyl alcohol method [23]. PCR amplification of DNA extracted from yeasts (Cryptoccocus neoformans, Candida parapsilopsis), gram positive cocci (Staphylococcus aureus, Streptoccocus pneumoniae), gram negative rods (Pseudomona aeruginos, Escherichia coli, Haemophilus influenzae), gram negative coccus (Neisseria meningitides) and herpes virus (Herpes simplex, Epstein Barr, Varicela Zoster, Cytomegalovirus) was performed to demonstrate the analytical specificity.

\section{Multiplex PCR for reference strains and clinical samples}

T. gondii DNA was amplified in reference strains and blood samples using the multiplex PCR assay, detecting two specific fragments from T. gondii genome. For reference strains, two microliters of DNA from Me49, C56, Tg51, CT1, Prug and OH3 strains were amplified independently under optimized conditions. For blood samples, five microliters of extracted DNA was added as template.

Each amplification run included two negative controls (ultra-pure water used in the mix PCR and a negative control of DNA extraction). For clinical samples, one positive control (DNA extracted from RH strain) was included.

Physical separation for mixture preparation, DNA extraction and visualization of PCR products were carried out and decontamination procedures were used in all areas to avoid contaminations. PCR products were analyzed by $2 \%$ agarose electrophoresis in $0.5 \mathrm{x}$ trisborate-EDTA (TBE) buffer, stained with ethidium bromide $(0.5 \mathrm{mg} /$ $\mathrm{ml}$ ) and visualized under UV illumination.

All clinical samples were evaluated in triplicated as independent samples. An inhibition test was done in all negative samples in order to discard PCR inhibitors. (i.e., DNA equivalent to 5 cells of T. gondii RH was added to the negative samples).

\section{Statistical analysis}

Predictive values, diagnostic sensitivity and specificity were calculated using the CDC criteria for TE as "gold standard" [24,25] EPIDAT 3.1 version program was used to calculate all the values.

\section{Ethic aspects}

Ethical approval for the study was obtained from the Institute of Tropical Medicine "Pedro Kourí" Ethic Committee, which followed international ethic criteria. Patients were informed about the study and a written informed consent from all of them or their relative closest was obtained. 


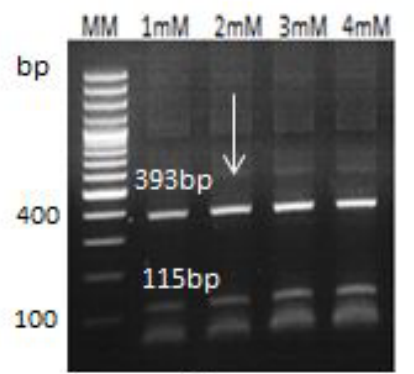

Fig. 1A

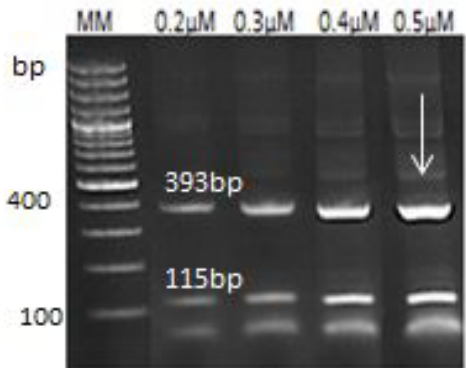

Fig. 1B

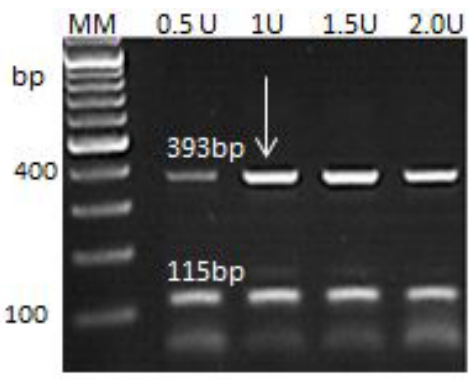

Fig. 1C

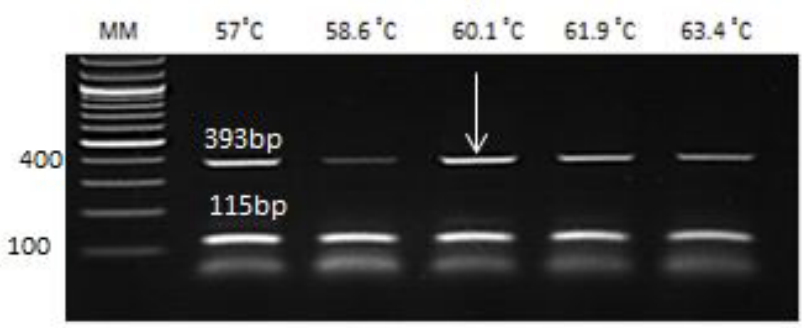

Fig. 1D

Figure 1: Agarose gel electrophoresis analysis after optimization process: MM: 100-bp ladder (Fermentas); (A) MgCl ; (B) primer (C) Go taq enzyme; (D) annealing temperature. Optimal concentrations are represented with white arrows as well as optimal temperature for annealing process.

\begin{tabular}{|l|l|l|}
\hline Protocol & Optimal concentrations & Amplification conditions \\
\hline \multirow{3}{*}{ MB1-529 } & Primers B22-B23: $0.5 \mu \mathrm{M}$ & $95^{\circ} \mathrm{C} 3 \mathrm{~min}$ \\
\cline { 2 - 3 } & Primers $529 \mathrm{~F}-529 \mathrm{R}: 05 \mu \mathrm{M}$ & $\begin{array}{l}35 \mathrm{cycles} \text { of }\left(95^{\circ} \mathrm{C} 30 \text { seconds, } 60.1^{\circ} \mathrm{C}\right. \\
\left.1 \mathrm{~min}, 72^{\circ} \mathrm{C} 1 \mathrm{~min}\right)\end{array}$ \\
\cline { 2 - 3 } & \begin{tabular}{l}
$72^{\circ} \mathrm{C} 5 \mathrm{~min}$ \\
\hline
\end{tabular} & $4^{\circ} \mathrm{C}$ \\
\hline
\end{tabular}

Table 3: Optimal concentrations of reagents and amplification conditions for multiplex PCR assay (MB1-529).

\section{Results}

\section{Optimization of multiplex PCR assay}

A multiplex PCR amplifying specific sequences for B1 gene and 529 bp element was evaluated in order to assess PCR efficiency detecting T. gondii in reference strains and blood samples from AIDS patients with TE.

During optimization, represented in Figure1, specific products were successfully amplified. Selected conditions are resumed in Table 3. For $\mathrm{MgCl}_{2}$ optimization resulted in similar efficiencies for 529 element. However, $2 \mathrm{mM}$ concentration is better for B1 fragment (Figure 1A). In contrast, PCR products intensity of both markers increased after increment primers concentration. At $0.5 \mu \mathrm{m}$, both bands look efficiently amplified. Polimerase (Gotaq) optimization resulted in similar high efficiency from $1 \mathrm{U}$ to $2.0 \mathrm{U}$. The annealing temperature gradient evidenced similar profile for B1 gene, while visual estimation of PCR product corresponding to 529 repetitive element was more intense at $57^{\circ} \mathrm{C}$ and $60.1^{\circ} \mathrm{C}$ (Figure 1D)

\section{Analytical sensitivity and specificity of multiplex PCR assay}

The multiplex assay was sensitive enough to detect as a faint band for both markers a minimum of one parasite. A representative agarose gel of PCR products is shown in Figure 2. No differences in analytical sensitivities were observed between the markers, even at low parasite concentrations. No product was produced using DNA from other microorganism described in section 2.5 (data not shown).

\section{Evaluation of multiplex PCR for reference strains and clinical samples}

To confirm the amplification of both markers in different $T$. gondii strains corresponding to isolations from different host, genetically different (Genotypes I,II,III) and phenotypically virulent and nonvirulent, DNA amplification was performed for each one independently. The PCR produced a $393 \mathrm{bp}$ and $115 \mathrm{bp}$ products in all six T. gondii strains that were tested, observing similar patterns, more intense for $393 \mathrm{bp}$ PCR products. Some unspecific bands appear up to 500bp (Figure 3).

For clinical samples, in 25/30 (86.6\%) cases from group I both marker were positives. In one case, DNA amplification did not occur for 529F-529R primers while, B22-B23 primer evidenced a clear amplification. However, statistically significant differences were not evident in the diagnostic sensitivity of the two markers independently analyzed. In group II, corresponding to patients without suspected TE,

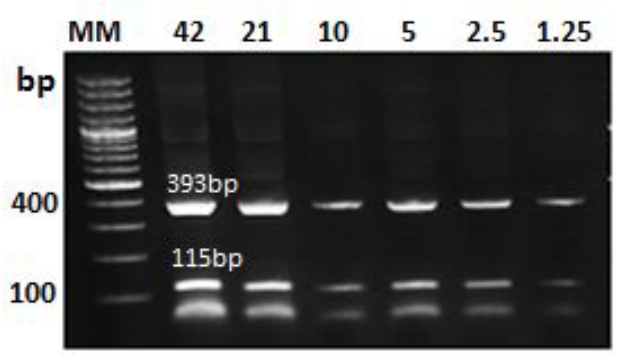

Figure 2: Analytical sensitivity of multiplex PCR assay. MM: 100-bp ladder (Fermentas); lane 1-6: number of parasites in the PCR amplification. 


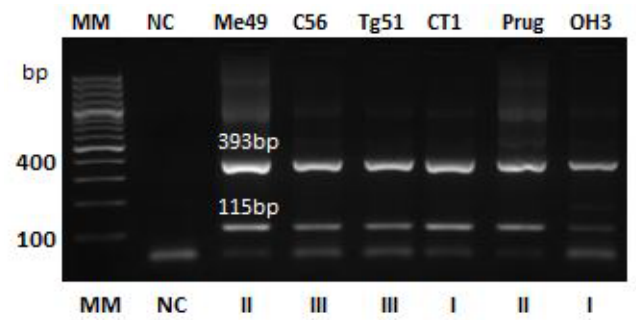

Figure 3: Agarose gel electrophoresis analysis of PCR amplification for DNA corresponding to different reference strains: MM: 100-bp ladder (Fermentas); lane NC: Negative Control for multiplex PCR mix; Me 49, C56, Tg51, CT1, Prug, $\mathrm{OH} 3$ : reference strains.

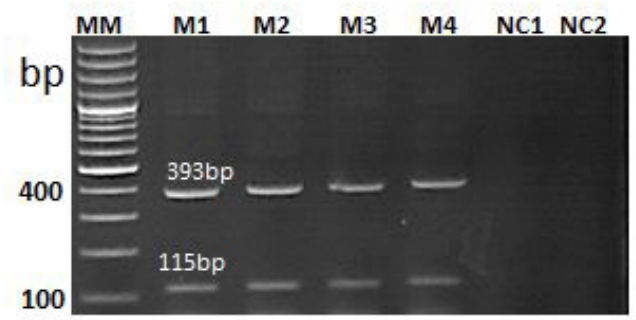

Figure 4: Agarose gel electrophoresis for four clinical samples (M1-4) after the evaluation of the multiplex PCR assay. MM: 100-bp ladder (Fermentas); lane M 1-4 clinical samples, NC1: Negative Control of multiplex PCR mix, NC2: negative Control of DNA extraction process.

\begin{tabular}{|l|c|c|c|r|r|r|}
\hline & Group I & Group 2 & Sensitivity (\%) & Specificity(\%) & PPV(\%) & NPV(\%) \\
\hline $\begin{array}{l}\text { Positive } \\
\text { MB1-529 }\end{array}$ & $26^{*}$ & 0 & 86.6 & 100 & 100 & 90.91 \\
\hline $\begin{array}{l}\text { Negative } \\
\text { MB1-529 }\end{array}$ & 4 & 40 & & & & \\
\hline
\end{tabular}

*one sample was positive only for B1 gene.

Table 4: Diagnostic efficiency of the multiplex PCR assay (MB1-529) after the evaluation of 70 blood samples from aids patients: sensitivity, specificity, PPVs, NPVs.

all results were negative. Table 4 shows the results of each individual primer set in detail and Figure 4 show a representation of the results obtained for three clinical samples.

\section{Discussion}

To reduce the cost and time for detecting the causative protozoan parasite in Toxoplasma encephalitis, we developed and evaluated a multiplex PCR using two "ideal targets" with remarkable sequence conservation $[11,26]$ which in theory increase the possibility of amplification wherever the genotype of the sample.

In order to amplify all specific PCR products with the similar efficiency, a carefully optimization of multiplex PCR mix components was performed. Ideally, in a multiplex PCR, the objective is enable similar amplification efficiencies for all targets [21]. However, contrarious phenomenon is known in multiplex PCRs that are designed to amplify more than one target simultaneously [27-29]. In our case, preferential amplification of 529 target sequence over B1 gene occurred in all the modification tested in the optimization. PCR selection process, defined as a mechanism which inherently favors the amplification of certain templates due to the properties of the target, the target's flanking sequences, or the entire target genome [30], could play an important role in our results. This phenomenon include interregional differences in GC content, leading to preferential denaturation; higher binding efficiency because of GC-rich primers; differential accessibility of targets within genomes due to secondary structures; and the gene copy number within a genome [30]. In these two sequences (B1 and 529), there are no significant differences in GC content flanking these target sequences. However, GC content for primer designed for 529 element is significant higher respect $\mathrm{B} 1$ gene and 529 element is repeated in tandem 200-300 times respect the 35 repetitions for the $\mathrm{B} 1$ gene, maybe leading these factors, to higher amplification efficiency for 529 element, and consequently more intense bands.

PCR on parasites dilutions evidenced that it is possible to amplify both targets in a multiplex assay with high analytical sensitivity, even at low parasite concentrations. At respect, it is important to note that below 10 parasites, there were no differences between electrophoresis patter for each marker. The same phenomenon occurred in the evaluation of blood samples. These results could evidence that at low parasite concentration in the clinical samples, the amplification could occur at the same time for both markers, reducing the cost and time for detecting T. gondii infection in routine assays. To amplified DNA from different reference strains, corresponding to different genotypes, in theory allow amplification wherever the genotype of $T$. gondii in the clinical sample. In practical terms, this methodology could be used in different geographical areas where different genotypes are prevalent.

Respect to use blood samples to diagnose Toxoplasmic encephalitis, this fluid have proven adequate diagnostic sensitivity and specificity in some studies $[7,19]$. The use of CSF looks better to diagnose the disease, but less invasive diagnosis in patients in which it is impossible to perform a lumbar puncture is necessary. In our study, 25/30 blood samples from group I (patients with TE) were positive for both targets in the multiplex assay, showing very similar visual estimation. The same event was observed at low parasite concentrations in the analytical sensitivity assay. These data indicate that the relative high proportion of 529 sequence respect B1 gene could be not evident at low parasite concentrations, at least using agarose electrophoresis to evaluate the final results in a non-quantitative PCR assay. At respect, in a clinical sample, the host DNA would be more abundant than the parasite's, maybe interfering in negative form in the accessibility to the specific regions and annealing process. In consequence amplification process is not completely efficient like occur when you use DNA from reference strains, which should be normally abundant respect host DNA one.

One sample was positive only by $\mathrm{B} 1$ gene. Easier amplification of a small fragment respect larger fragments in the same template could occur. No inhibition was observed in the traditional inhibition test. The amplification for one marker in the multiplex assay constitutes another inhibition test. In a practice point of view, to amplify two sequences by PCR in a multiplex assay is not only less expensive and time consuming. It is an efficient way to evaluate false negative results for one target respect the other and to discard rapidly an inhibition of the amplification, using the same DNA extraction conditions and the same DNA concentration in the same sample.

Even when nested PCR increases the diagnostic sensitivity of PCR methodologies, it also complicates the practical application of multiplex PCR. The second round of amplification delays results and increases the chance of cross-contamination [21]. In our case, we considered not practice to design a nested PCR to increase the diagnostic sensitivity.

Results of comparisons for these two sequences in independent studies are variable. Four studies comparing these markers demonstrated higher sensitivity for 529 repetitive element [12-14,16]. 
In opposition, three studies found that $\mathrm{B} 1$ gene is more adequate target for the detection of T. gondii in different clinical sceneries [18-20]. The higher sensitivity reported for $\mathrm{B} 1$ gene in these last correspond to B22-B23 primers reported by Bretagne et al, 1993 while these primers were not evaluated in the first four studies. More recently, Stekers et al. (2010), in a multicenter comparative analytical performance study for molecular detection of $T$. gondii show that 529 element is better for the diagnosis of congenital toxoplasmosis than the widely used B1 gene. However, only 1/6 laboratories comparing both sequences included B22-B23 primers [21]. In that form, there are not concluding remarks about the best sequence and both markers look efficient to detect $T$. gondii DNA in clinical samples. In addition, B22-B23 could represent one of the best primers designed for the B1 gene. In our case, B22-B23 set of primers was more efficient to detect $T$. gondii DNA in clinical samples but this difference was not significant.

In this study, we designed a new and rapid diagnostic method based on Multiplex PCR to detect T. gondii DNA. Even when the results requires expansion to make it more useful in practical scenario, it has the potential to produce considerable savings of time and effort within the laboratory, without compromising test utility, minimizing the time and avoiding contaminations. It is possible to use this assay to detect T. gondii DNA in blood samples avoiding independent PCR assays for each marker with high specificity, easy performance, enough sensitivity, speed, no additional PCR test, no additional volume of sample, no a second electrophoresis and a reduction of contamination.

\section{References}

1. Luft BJ, Remington JS (1992) Toxoplasmic encephalitis in AIDS. Clin Infect Dis 15: 211-222.

2. Montoya JG, Liesenfeld O (2004) Toxoplasmosis. Lancet 363: 1965-1976.

3. Antinori A, Larussa D, Cingolani A, Lorenzini P, Bossolasco S, et al. (2004) Prevalence associated factors and prognostic determinants of AIDS-related toxoplasmic encephalitis in the era of advanced high active antiretroviral therapy. Clinical Infectious Diseases 39: 1681-1691.

4. Vidal JE, Hernandez AV, de Oliveira AC, Dauar RF, Barbosa SP Jr, et al. (2005) Cerebral toxoplasmosis in HIV-positive patients in Brazil: clinical features and predictors of treatment response in the HAART era. AIDS Patient Care STDS 19: 626-634.

5. Bretagne S, Costa JM, Vidaud M, Tran J, Nhieu V, Fleury-Feith J (1993) Detection of Toxoplasma gondii by competitive DNA amplification of bronchoalveolar lavage samples. J Infect Dis 168: 1585-1588.

6. Vidal JE, Colombo FA, de Oliveira AC, Focaccia R, Pereira-Chioccola VL (2004) PCR assay using cerebrospinal fluid for diagnosis of cerebral toxoplasmosis in Brazilian AIDS patients. J Clin Microbiol 42: 4765-4768.

7. Colombo FA, Vidal JE, Penalva de Oliveira AC, Hernandez AV, Bonasser-Filho F, et al. (2005) Diagnosis of cerebral toxoplasmosis in AIDS patients in Brazil: importance of molecular and immunological methods using peripheral blood samples. J Clin Microbiol 43: 5044-5047.

8. Alfonso Y, Fraga J, Jiménez N, Fonseca C, Dorta-Contreras AJ, et al. (2009) Detection of Toxoplasma gondii in cerebrospinal fluid from AIDS patients by nested PCR and rapid identification of type I allele at B1 gene by RFLP analysis. Exp Parasitol 122: 203-207.

9. Alfonso Y, Fraga J, Cox R, Jiménez N, Capó V, et al. (2013) Conventional PCR for the diagnosis of NTx: Comparison of three set of primers for the B1 gene using CSF samples. Diag Microbiol Infect Dis 75: 150-4.

10. Burg JL, Grove CM, Pouletty P, Boothroyd JC (1989) Directed and sensitive detection of a pathogenic protozoan, Toxoplasma gondii, by polymerase chain reaction. J Clin Microbiol 27: 1787-1792.

11. Homan W, Vercammen M, De Braekeleer J, Verschueren H (2000) Identification of a 200 to 300 fold repetitive 529 bp DNA fragment in Toxoplasma gondii, and its use for diagnostic and quantitative PCR. Int J Parasitol 30: 69-75.

12. Filisetti D, Gorcii M, Pernot-Marino E, Villard O, Candolfi E (2003) Diagnosis of congenital toxoplasmosis: comparison of targets for detection of Toxoplasma gondii by PCR. J Clin Microbiol 41: 4826-4828.
13. Reischl U, Bretagne S, Krüger D, Ernault P, Costa JM (2003) Comparison of two DNA targets for the diagnosis of Toxoplasmosis by real-time PCR using fluorescence resonance energy transfer hybridization probes. BMC Infect Dis 3: 7 .

14. Hierl T, Reischl U, Lang P, Hebart H, Stark M, et al. (2004) Preliminary evaluation of one conventional nested and two real-time PCR assays for the detection of Toxoplasma gondii in immunocompromised patients. J Med Microbiol 53: 629-632.

15. Calderaro A, Piccolo G, Gorrini C, Peruzzi S, Zerbini L, et al. (2006) Comparison between two real-time PCR assays and a nested-PCR for the detection of Toxoplasma gondii. Acta Biomed 77: 75-80.

16. Cassaing $\mathrm{S}$, Bessières $\mathrm{MH}$, Berry A, Berrebi A, Fabre R, et al. (2006) Comparison between two amplification sets for molecular diagnosis of toxoplasmosis by real-time PCR. J Clin Microbiol 44: 720-724.

17. Chabbert E, Lachaud L, Crobu L, Bastien P (2004) Comparison of two widely used PCR primer systems for detection of Toxoplasma in amniotic fluid, CSF and tissues. J Clin Microbiol 42: 1719-1722.

18. Okay TS, Yamamoto L, Oliveira LC, Manuli ER, Andrade Junior HF, et al (2009) Significant performance variation among PCR systems in diagnosing congenital toxoplasmosis in São Paulo, Brazil: analysis of 467 amniotic fluid samples. Clinics (Sao Paulo) 64: 171-176.

19. Mesquita RT, Vidal JE, Pereira-Chioccola VL (2010) Molecular diagnosis of cerebral toxoplasmosis: comparing markers that determine Toxoplasma gondii by PCR in peripheral blood from HIV-infected patients. Braz J Infect Dis 14 346-350.

20. Wahab T, Edvinsson B, Palm D, Lindh J (2010) Comparison of the AF146527 and B1 repeated elements, two real-time PCR targets used for detection of Toxoplasma gondii. J Clin Microbiol 48: 591-592.

21. Sterkers Y, Varlet-Marie E, Cassaing S, Brenier-Pinchart MP, Brun S, et al (2010) Multicentric comparative analytical performance study for molecular detection of low amounts of Toxoplasma gondii from simulated specimens. J Clin Microbiol 48: 3216-3222

22. Centers for Disease Control and Prevention (1993) Revised classification system for HIV infection and expanded surveillance case definition for AIDS among adolescents and adults. JAMA 10: 729-730.

23. Sambrook J, Fritsch EF, Maniatis T (1989) Molecular cloning, a laboratory manual (2ndedn). Cold Spring Harbor. Cold Spring Harbor Laboratory Press1-3.

24. Altman DG, Bland JM (1994a) Statistics Notes: Diagnostic tests 1: sensitivity and specificity. Brithish Medical Journal 308: 1552.

25. Altman DG, Bland JM (1994) Diagnostic tests 2: Predictive values. BMJ 309: 102.

26. Grigg ME, Boothoroyd JC (2001) Rapid identification of virulent Tipe I strain of the protozoan pathogen Toxoplasma gondii by PCR-Restriction Fragment Length Polimorphism Analysis at the B1 gene. J Clin Microbiol 39: 398-400.

27. Polz MF, Cavanaugh CM (1998) Bias in template-to-product ratios in multitemplate PCR. Appl Environ Microbiol 64: 3724-3730.

28. Walsh PS, Erlich HA, Higuchi R (1992) Preferential PCR amplification of alleles: mechanisms and solutions. PCR Methods Appl 1: 241-250.

29. Mutter GL, Boynton KA (1995) PCR bias in amplification of androgen receptor alleles, a trinucleotide repeat marker used in clonality studies. Nucleic Acids Res 23:1411-1418.

30. Suzuki MT, Giovannoni SJ (1996) Bias caused by template annealing in the amplification of mixtures of $16 \mathrm{~S}$ rRNA genes by PCR. Appl Environ Microbiol 62: $625-630$ 